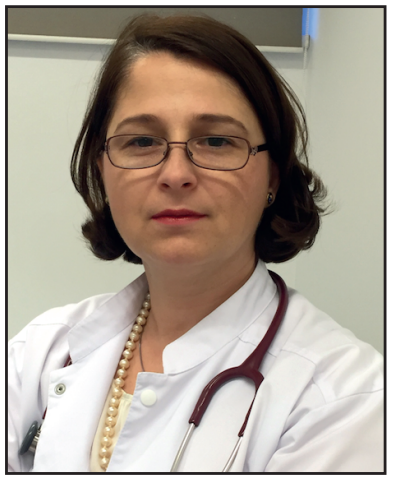

Camelia DIACONU $\bowtie$

International Secretary General of the Balkan Medical Union President of the Romanian National Section

Secrétaire Général International de l'Union Médicale Balkanique Présidente de la Section Nationale Roumaine

\section{STATINS AND HEART FAILURE}

Chronic heart failure is a syndrome that appears in the evolution of a large majority of cardiovascular diseases. The main risk factors for chronic heart failure are arterial hypertension, coronary heart disease, diabetes mellitus, obesity, dyslipidemia etc. Over the years, researchers have been intensively studied new approaches and treatments to prevent the development of heart failure, to slow the evolution or to increase survival in patients with this syndrome. Dyslipidemia is a risk factor for chronic cardiovascular diseases, especially coronary heart disease. HMG-CoA reductase inhibitors (statins) are largely used for the treatment of hypercholesterolemia and coronary heart disease. Considering the beneficial effects of statins for the prevention and treatment of cardiovascular diseases, some studies suggested that these drugs can be beneficial in the context of chronic heart failure ${ }^{1-3}$. However, a "cholesterol paradox" has been recognized in patients with heart failure: although hypercholesterolemia is a risk factor for coronary artery disease, low cholesterol seems to be associated with a poor prognosis in patients with already installed heart failure, as compared with those without heart failure ${ }^{4-6}$. This is named „the cholesterol paradox". There are multiple possible explanations for this paradox. Cholesterol is a marker of nutritional status in patients with mild to moderate heart failure. The congestive hepatopathy of patients with chronic heart failure may lead to decreased liver synthesis of cholesterol ${ }^{2}$. Also, the intestinal congestion

\section{STATINES ET L'INSUFFI- SANCE CARDIAQUE}

L'insuffisance cardiaque chronique est un syndrome qui apparaît dans l'évolution d'une grande majorité de maladies cardiovasculaires. Les principaux facteurs de risque d'insuffisance cardiaque chronique sont l'hypertension artérielle, les maladies coronariennes, le diabète sucré, l'obésité, la dyslipidémie, etc. Au fil des années, les chercheurs ont étudié de manière approfondie de nouvelles approches et de nouveaux traitements pour prévenir le développement de l'insuffisance cardiaque, ralentir son évolution ou augmenter la survie chez les patients atteints de ce syndrome. La dyslipidémie est un facteur de risque de maladies cardiovasculaires chroniques, en particulier des maladies coronariennes. Les inhibiteurs de l'HMG-CoA réductase (statines) sont largement utilisés pour le traitement de l'hypercholestérolémie et des maladies coronariennes. Considérant les effets bénéfiques des statines sur la prévention et le traitement des maladies cardiovasculaires, certaines études ont suggéré que ces médicaments pouvaient être bénéfiques dans le contexte de l'insuffisance cardiaque chronique ${ }^{1-3}$. Cependant, un "paradoxe du cholestérol» a été reconnu chez les patients insuffisants cardiaques: bien que l'hypercholestérolémie soit un facteur de risque de coronaropathie, un faible taux de cholestérol semble être associé à un mauvais pronostic chez les patients déjà insuffisants cardiaques, insuffisance cardiaque ${ }^{4-6}$. C'est ce qu'on appelle «le paradoxe du cholestérol». Plusieurs explications sont possibles pour ce paradoxe. Le cholestérol 
in these patients may impair the absorption of cholesterol'. Studies have found that low serum cholesterol is secondary to the severity of the heart failure, as in other chronic diseases. However, it is not yet known if low cholesterol is the cause of a worse prognosis in heart failure or it is only a marker of more severe disease.

On one hand, statins have pleiotropic effects that could be beneficial in heart failure, such as stabilization of atheromatous plaques, inhibition of proinflammatory cytokine activity and even antiarrhythmic effect ${ }^{8}$. On the other hand, statins may be harmful in patients with heart failure, raising their susceptibility to infections, because lipoproteins remove bacterial endotoxins from the circulation?. Treatment with statins reduces the level of coenzyme Q10, which plays a role in the mitochondrial respiration and influences the contractile activity of the myocardium $^{10}$. The serum level of coenzyme Q10 is inversely correlated to mortality of patients with heart failure ${ }^{10}$.

A meta-analysis of 15 studies including 45,110 patients with heart failure, from whom 22,471 were treated with statins, revealed that patients who received a statin had a lower all-cause mortality rate and rehospitalization for heart failure ${ }^{11}$. Two studies, CORONA and GISSI-HF, suggested that patients with systolic heart failure do not benefit from initiation of statin therapy ${ }^{12,13}$. CORONA trial suggested that rosuvastatin might be beneficial in patients with ischemic heart disease and systolic heart failure, with NT-proBNP value $<868 \mathrm{pg} / \mathrm{mL}^{12}$. The negative results of these two studies are in contrast with numerous other small studies which have demonstrated the beneficial effects of statins in heart failure patients ${ }^{14}$. The clinical trials did not search if patients already taking a statin, who develop heart failure, benefit from continuation of statin treatment. Until further studies will clarify these issues, it seems reasonable that patients already on statin for another strong indication, developing heart failure, should continue the statin. Patients with systolic heart failure, with a left ventricle ejection fraction $<35 \%$, should receive a statin, according to CORONA trial results ${ }^{12}$. The decision to start a statin in patients with heart failure with preserved ejection fraction is usually based upon other indication, such as high LDL-cholesterol values or documented atherosclerotic vascular disease. est un marqueur de l'état nutritionnel chez les patients atteints d'insuffisance cardiaque légère à modérée. L'hépatopathie congestive des patients souffrant d'insuffisance cardiaque chronique peut entraîner une diminution de la synthèse du cholestérol par le $f_{0 i e}{ }^{2}$. En outre, la congestion intestinale chez ces patients peut nuire à l'absorption du cholestérol'. Des études ont montré qu'un faible taux de cholestérol sérique est secondaire à la gravité de l'insuffisance cardiaque, comme dans d'autres maladies chroniques. Cependant, on ne sait pas encore si un faible taux de cholestérol est la cause d'un mauvais pronostic en cas d'insuffisance cardiaque ou s'il ne s'agit que d'un marqueur d'une maladie plus grave.

D'une part, les statines ont des effets pléiotropes qui pourraient être bénéfiques en cas d'insuffisance cardiaque, tels que la stabilisation des plaques d'athérome, l'inhibition de l'activité des cytokines pro-inflammatoires et même l'effet anti-arythmique ${ }^{8}$. En revanche, les statines peuvent être nocives chez les patients insuffisants cardiaques, en augmentant leur vulnérabilité aux infections, car les lipoprotéines éliminent les endotoxines bactériennes de la circulation?. Le traitement aux statines réduit le taux de coenzyme Q10, qui joue un rôle dans la respiration mitochondriale et influence l'activité contractile du myocarde ${ }^{10}$. Le taux sérique de coenzyme Q10 est inversement corrélé à la mortalité des patients insuffisants cardiaques ${ }^{10}$.

Une méta-analyse de 15 études incluant 45110 patients insuffisants cardiaques, dont 22471 ont été traités avec des statines, a révélé que les patients recevant une statine présentaient un taux de mortalité inférieur de toute cause et de ré-hospitalisation pour insuffisance cardiaque ${ }^{11}$. Deux études, CORONA et GISSI-HF, ont suggéré que les patients souffrant d'insuffisance cardiaque systolique ne bénéficiaient pas du traitement par statines ${ }^{12,13}$. L'étude CORONA a suggéré que la rosuvastatine pourrait être bénéfique chez les patients présentant une cardiopathie ischémique et une insuffisance cardiaque systolique, avec une valeur de NT-proBNP $<868 \mathrm{pg} / \mathrm{mL}^{12}$. Les résultats négatifs de ces deux études se mettent en contraste avec de nombreuses autres petites études qui ont démontré les effets bénéfiques des statines chez les patients insuffisants cardiaques ${ }^{14}$. Les essais cliniques n'ont pas cherché à savoir si les patients prenant déjà une statine, présentant une insuffisance cardiaque, bénéficieraient de la poursuite du traitement par la statine. Jusqu'à ce que d'autres études clarifient ces problèmes, il semble raisonnable que les patients qui prennent déjà une statine pour une autre indication forte, une insuffisance cardiaque en développement, continuent à prendre cette statine. Les patients présentant une insuffisance cardiaque systolique, avec 
une fraction d'éjection du ventricule gauche $<35 \%$, devraient recevoir de la statine, selon les résultats de l'essai CORONA ${ }^{12}$. La décision de démarrer un traitement aux statines chez les patients insuffisants cardiaques avec une fraction d'éjection préservée est généralement basée sur d'autres indications, telles que des valeurs élevées du cholestérol LDL ou une maladie vasculaire athérogène documentée.

\section{„No conflict of interest.“}

\section{References}

1. Catapano AL, Graham I, De Backer G, et al. 2016 ESC/EAS guidelines for the management of dyslipidaemias. Eur Heart J. 2016;37:2999-3058.

2. Ananaba I, Taegtmeyer H. Low serum cholesterol as prognostic indicator in heart failure. J Card Fail. 2012;18:596.

3. Rauchhaus M, Clark AL, Doehner W, et al. The relationship between cholesterol and survival in patients with chronic heart failure. J Am Coll Cardiol. 2003;42:1933- 40.

4. Afsarmanesh N, Horwich TB, Fonarow GC. Total cholesterol levels and mortality risk in nonischemic systolic heart failure. Am Heart J. 2006;152:1077-83.

5. Horwich TB, Hernandez AF, Dai D, Yancy CW, Fonarow GC. Cholesterol levels and in-hospital mortality in patients with acute decompensated heart failure. Am Heart J. 2008;156:1170-6.

6. Weiss A, Beloosesky Y, Schmilovitz-Weiss H, Grossman E, Boaz M. Serum total cholesterol: a mortality predictor in elderly hospitalized patients. Clin Nutr. 2013;32:533-7.

7. Chen Y, He XM, Meng H, et al. Relationship between lipids levels and right ventricular volume overload in congestive heart failure. J Geriatr Cardiol. 2014;11: 192-9.

8. Ramasubbu K, Estep J, White DL, et al. Experimental and clinical basis for the use of statins in patients with ischemic and nonischemic cardiomyopathy. J Am Coll Cardiol. 2008; 51:415.

9. Rauchhaus M, Coats AJ, Anker SD. The endotoxin-lipoprotein hypothesis. Lancet 2000; 356:930.

10. Molyneux SL, Florkowski CM, George PM, et al. Coenzyme Q10: an independent predictor of mortality in chronic heart failure. J Am Coll Cardiol 2008; 52:1435.

11. Wang JQ, Wu GR, Wang Z, et al. Long-term clinical outcomes of statin use for chronic heart failure: a meta-analysis of 15 prospective studies. Heart Lung Circ 2014; 23:105.

12. Cleland JG, McMurray JJ, Kjekshus J, et al. Plasma concentration of amino-terminal pro-brain natriuretic peptide in chronic heart failure: prediction of cardiovascular events and interaction with the effects of rosuvastatin: a report from CORONA (Controlled Rosuvastatin Multinational Trial in Heart Failure). J Am Coll Cardiol 2009; 54:1850.

13. Tavazzi L, Maggioni AP, Marchioli R, et al. Effect of rosuvastatin in patients with chronic heart failure (the GISSI-HF trial): a randomized, double-blind, placebo-controlled trial. Lancet 2008; 372:1231.

14. White J, Stewart R. Bias in the evaluation of effects of statins on mortality in patients with heart failure. Heart Lung Circ 2014;23:989-90. 